\title{
CZECH EXPORTS AND GERMAN GDP: A CLOSER LOOK
}

\section{Josef Taušer, Markéta Arltová, Pavel Žamberský*}

\begin{abstract}
:
This paper analyses the relation between Czech exports in goods and services and German GDP. In order to contribute to the current state of knowledge the analysis goes more into detail in terms of disaggregating the German GDP. Do Czech exports depend more on German domestic absorption, or is it, rather, German exports which determine Czech exports? Does the Czech Republic produce goods for German consumers or is it an "outsourced" supplier to German export channels, instead? Co-integration analysis and the analysis of the commodity structure of Czech exports to Germany are employed to address these questions. The findings of this research indicate that the relationship between Czech exports and German GDP is a very complex one. The Czech economy can be considered a part of German distribution channels, which serves as its specialized outsourced production capacity.
\end{abstract}

Keywords: determinants of Czech exports, commodity structure of Czech exports, export concentration and diversification, co-integration analysis, ADL model, EC model

JEL Classification: C5, F14

\section{Introduction}

The Czech Republic is a small open economy with a very high ratio of export in goods to gross domestic product (GDP), relatively speaking. According to data from the Czech Statistical Office (CZSO, 2012) the ratio reached almost 75\% in 2011, whereas more than $32 \%$ of Czech exports went to Germany in the same year (CZSO, 2012). Economic development in Germany can, therefore, be considered a critical factor in determining the GDP growth of the Czech Republic. Thus, the analysis of the relationship between Czech exports and German GDP is of great relevance and importance.

How strongly dependent are Czech exports on German GDP? What are the forces behind this basic relationship? Do Czech exports depend more on German domestic absorption, or is it that German exports determine Czech exports? Does the Czech Republic produce goods for German consumers or is it, instead, an "outsourced" supplier to German export channels?

* Josef Taušer, Vysoká škola ekonomická v Praze, Department of International Trade, Prague, Czech Republic (tauser@vse.cz); Markéta Arltová, Vysoká škola ekonomická v Praze, Faculty of Informatics and Statistics, Prague, Czech Republic (arltova@vse.cz); Pavel Žamberský, Vysoká škola ekonomická v Praze, Faculty of International Relations, Prague, Czech Republic (pavel.zambersky@vse.cz). This article was elaborated within the Research Plan MSMT MSM6138439909 Governance in Context of Globalised Economy and Society carried out at the Faculty of International Relations, University of Economics in Prague, Czech Republic and with the support of Grant Agency of the Czech Republic No. P402/12/G097 DYME - Dynamic Models in Economics. 
In this article we try to address these questions. Thus, the main goal of our paper is to provide an in-depth analysis of relations between Czech exports and German GDP. For this purpose we will run 3 rounds of co-integration analysis, and construct 3 ADL and EC models to investigate the short and long-term relations between: 1) Czech exports and German GDP, 2) Czech exports and German domestic absorption, and German exports, and finally: 3) Czech exports and German private consumption, German investments and German government expenditures. The results of the empirical analysis will then be compared to the detailed analysis of the commodity structure of Czech exports to Germany in order to support the findings of the econometric analysis and to come up with consistent interpretations. Finally, we will summarize the main findings and draw the relevant conclusions.

\section{Theoretical Framework and Literature Review}

According to standard open economy macroeconomics, domestic exports should be defined as a function of foreign income (gross domestic product, GDP) and real exchange rate; see for example Krugman, Obstfeld (2000), Obstfeld, Rogof (1996), Blanchard (2000) and Gandolfo (1986).

The relationship between domestic exports and foreign income is generally considered to be straightforward. If foreign GDP rises, foreign consumers have a higher income which they use to buy more products and services both at home and abroad, thus increasing the imports to the domestic economy. Statistically significant positive relations between both variables have been confirmed by many studies. Majeed, Mahmad (2006) analyse the determinants of exports in developing countries using the panel data of 75 countries for the period 1970-2004 and have found that GDP and its growth generally have a positive impact on exports. Kaus (2008) investigates the determinants of Chinese and Indian exports on both the demand and supply sides, and concludes that the general level of foreign income in importing countries has been identified as a statistically significant explanatory variable of exports. Particularly in the case of Czech exports, the relationship between exports and foreign income has been investigated, for instance, by Tomšík (2000, 2001) and Havrlant, Hušek (2011). All 3 studies have come to the conclusion that Czech exports depend on the GDP of the main trading partner(s).

As for the real exchange rate, a positive relationship between the variable and exports is assumed. Real depreciation (increase in the value) ${ }^{1}$ reduces the relative costs of domestic producers vis-à-vis foreign competitors, or it increases their relative profits. Domestic producers become more competitive with prices which should boost their exports.

The empirical analysis of the real exchange rate channel is, however, more difficult. Firstly, the results may depend on the price indices which we use in the formula (Havrlant, Hušek, 2011). Secondly, there could be a strong relationship between the nominal exchange rate and the domestic price level. Thus, the positive effect of nominal depreciation on domestic exports could be eliminated by the increased costs of production because

1 Real depreciation means that with respect to the previous period, more domestic consumer baskets should now be sacrificed in exchange for one foreign consumer basket. Real depreciation can be driven by depreciation of the nominal exchange rate, by an increase in foreign price levels, by a decrease in domestic price levels or by any combination of these three factors which results in a final decrease of domestic comparative price levels. 
of the increased prices of imported products and its spill-over effects on the prices of domestic products and wages; see for example Velickovski, Pugh (2011) or Lin, Ye (2012). Thirdly, the substantial part of real appreciation in transition economies may be explained by the price convergence process assuming that real appreciation refers only to nontradable goods, and may therefore not influence domestic exports to any significant extent. This idea is based on the so called Balasa-Samuelson effect which has been presented by Balassa (1964) and Samuelson (1964), and was further discussed by Pilbeam (1992) and investigated by Podkraminer (2010), Čihák, Holub (2000, 2003), Vintrová (2007) and many others. Fourthly, there could be a strong relationship between the real exchange rate and terms of trade, which should be, therefore, also included in the analysis; see for example Dungey (2004) or Nešvera (2006).

Besides foreign income and real exchange rates, there are lots of other variables which may affect domestic exports. The inflow of foreign direct investments could be a very important factor, especially for transition economies where export oriented foreign direct investments seek to profit from cheaper labour forces and other costs of production. Mandel, Tomšík (2008) provide a theoretical explanation of the so called financial life cycle of the investments and analyse its impact on the balance of payments of selected Central and Eastern European countries. According to their findings, foreign direct investments influence the balance of payments of the respective countries, whereas the nature of the impact depends on the particular stage of the lifecycle of the investment. Majeed, Mahmad (2006) confirm the positive effect of FDI on the exports of some developing countries, while simultaneously rejecting this effect in the case of other developing countries. Vural, Zortuk (2011) investigate the determinants of Turkish exports and found that FDI have a significant positive impact on the export performance of that country.

The gravity model is another tool which can be applied to analyse and explain trade flows. In its basic form it involves the following variables: the scale of trading partner economies, their geographical, social and cultural proximity (Wilson et al., 2005). The model became widely popular and has been extended by many other variables. Ali, Sami (2011) employ the gravity trade model to explain Tunisian exports to nontraditional partner countries, and they have found that Tunisian exports go mainly to nearby countries as well as to countries with common maritime borders. Rose (2004) analyses the panel data of 178 economies for the period of 1948-1999 using, for instance, the following explanatory variables: landlocked position of either or both of the partner economies, land area, common colonizer and nationality, use of the same currency, GATT/WTO membership, status of GSP beneficiary etc. with the aim of evaluating the effect of GATT/WTO membership on trade. Surprisingly, he found that membership does not affect the trade to the extent expected, whereas other gravity effects have been more or less confirmed.

There are also many studies which investigate other rather specific export determinants. Just a small sample will be listed here as an example. Kaus (2008) found the negative effect of value-added tax and higher wages, and the positive effect of the share of exports by foreign invested companies, value added in output and export experience on Chinese exports. Turner (2011) uses a data set of 27 sectors from over 120 countries to investigate the impact of access to financial resources, and the overall development of the financial sector on the supply of exports, and finds that it depends both on the extent to which the sector relies on external finance, as well as on the financial channels available. 
Majeed, Mahmad (2006) prove that, inter alia, the development of communications infrastructure significantly promotes exports in developing countries. Agosin et al. (2012) mention the importance of human capital for the respective countries' exports. The study uses a lot of data covering 79 countries in the period 1962-2000 in order to investigate the determinants of export diversification.

As can be seen, the number of potential export determinants is relatively large. Thus, the research scope in this area is very wide. In our research we build mainly on the studies by Tomšík (2000, 2001) and Havrlant, Hušek (2011). But instead of extending the models with further variables, or applying different research methods, we decided to focus only on the relationship between Czech exports and German GDP with the aim of providing more in-depth analysis of this relationship while neglecting all other variables, although we are fully aware of their potential impact. This approach is consistent with the main goals of our paper, as well as with our initial motivation beyond the research. We believe that leaving out all the other factors enables us to analyse the key dependence of Czech exports in more circumstances, as well as coming up with some new findings which could contribute to the current state of knowledge in this area.

For detailed analysis of the relationships between Czech exports and German GDP we will split German GDP into its domestic absorption and net export components. Domestic absorption will then be further broken down into the private consumption, gross domestic investments and government expenditures.

\section{Co-integration Analysis}

In this chapter, we will employ standard econometric tools to closely investigate the relationship between Czech exports in goods and services (EXCZE) and German GDP (GDPGER).

The analysis will be conducted in 3 steps. Firstly, we will analyse the dependence of Czech exports on German GDP, generally. Secondly, we will focus on the dependence of Czech exports on German domestic absorption (ABSGER), and German exports $(E X G E R)$. Thirdly, we will analyse the dependence of Czech exports on German private consumption (CONGER), gross domestic investments (INVGER) and government expenditures (GOVGER).

The analysis will be based on quarterly data for the period of I/2000-II/2012 obtained from official sources - the Czech National Bank as well as the German Statistical Office. As for the Czech exports in goods and services, we will use the data based on ownership principle (national concept) which is more accurate in this case; for more details see Rojíček, Koštáková, Sixta (2010, 2011 and 2012). All time series are measured in billions of EUR.

All time series need to be seasonally adjusted. For this purpose we have used X12ARIMA method (U.S. Census Bureau, 2004). According to the results of the Augmented Dickey-Fuller tests (ADF tests) (Dickey, Fuller, 1979) in Table 1, all the analysed time series are non-stationary and integrated to the order 1, i.e. I(1). 
Table 1

Unit Root Test of the Seasonal Adjusted Time Series and of the First Differences

\begin{tabular}{|l|c|c|c|c|}
\hline \multirow{2}{*}{ I/2000-II/2012 } & \multicolumn{2}{|c|}{ Seasonal Adjusted Time Series } & \multicolumn{2}{c|}{ First Differences } \\
\cline { 2 - 5 } & $t_{A D F}$ & Prob. & $t_{A D F}$ & 0.0000 \\
\hline EXCZE & 2.491195 & 0.9964 & -4.600626 & 0.0001 \\
\hline GDPGER & 0.029364 & 0.9566 & -5.277953 & 0.0000 \\
\hline EXGER & 0.583449 & 0.9879 & -6.449731 & 0.0022 \\
\hline INVGER & -0.711667 & 0.8339 & -4.109982 & 0.0000 \\
\hline GOVGER & -2.107201 & 0.2428 & -7.735552 & 0.0000 \\
\hline
\end{tabular}

Source: own calculations

The analysis of the relationship between the integrated time series makes sense only if these time-series share common stochastic trends, which means that they are co-integrated. If the time series are not co-integrated, we may not apply regression analysis because of the risk of the so called spurious regression (Granger, Newbold, 1974). We therefore use the Engle-Granger test for co-integration (Engle, Granger, 1987) to identify spurious regression. The model tests the stationarity of the residuals of following statistic regression model:

$$
Y_{t}=\beta X_{t}+a_{t}
$$

If the residuals of the model $a_{t}$ are stationary $\mathrm{I}(0)$ then, the respective time-series are co-integrated. If the residuals are non-stationary I(1), then the relationship is based on spurious regression.

After identifying the co-integrated relations we employ Autoregressive Distributed Lag model - ADL (Hendry, Pagan, Sargan (1984)), for example ADL(1,1) model has form:

$$
Y_{t}=c+\alpha_{1} Y_{t-1}+\beta_{1} X_{t}+\beta_{2} X_{t-1}+a_{t}
$$

Further, we derive the so called Error Correction Model - ECM (Engle, Granger, 1987) to distinguish between short-term and long-term relations:

$$
\Delta Y_{t}=c+\beta_{1} \Delta X_{t}+\gamma\left(Y_{t-1}-\beta X_{t-1}\right)+a_{t}
$$

where $\beta=\left(\beta_{1}+\beta_{2}\right) /\left(1-\alpha_{1}\right)$ and $\gamma=\alpha_{1}-1$. If parameter $\gamma=0$, there is no cointegration between the time series (Arlt et al., 2001).

In accordance with the theory (see the previous chapter) we use only one-equation models, in which Czech exports are always an endogenous variable, whereas all the other variables are considered to be of an exogenous nature (Arlt, Arltová, 2009). 


\subsection{Dependence of Czech exports and German GDP}

\section{Figure 1}

Czech Exports (in billion EUR) and German GDP (in billion EUR) in the Period of I/2000-II/2012

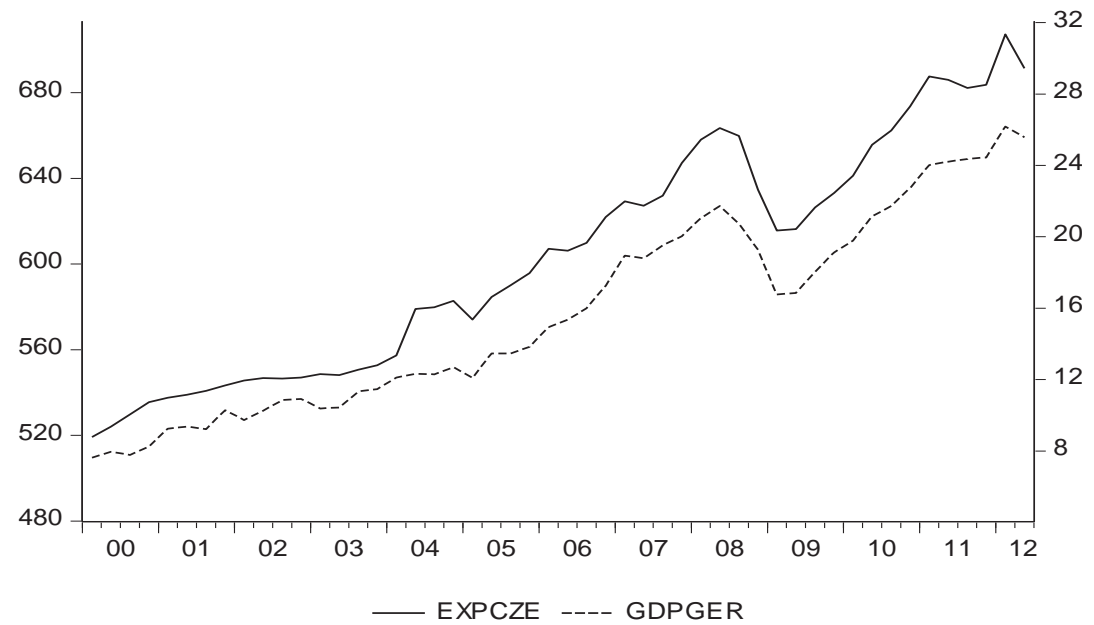

Source: data from Czech National Bank and German Statistical Office

As it can be seen from the Figure 1 and Table 1, both time series are non-stationary of the order 1, i.e. I(1). Thus, we need to apply the Engle-Granger test for cointegration in order to avoid the spurious regression.

\section{Table 2}

Engle-Granger Test for Co-integration

\begin{tabular}{|l|c|c|c|c|}
\hline \multicolumn{5}{|c|}{ Null hypothesis: Series are not cointegrated } \\
\hline Dependent & tau-statistic & Prob. & z-statistic & Prob. \\
\hline EXCZE & -3.532677 & 0.0429 & -20.83351 & 0.0254 \\
\hline GDPGER & -3.458022 & 0.0506 & -20.54462 & 0.0275 \\
\hline
\end{tabular}

Source: own calculations

According to the results of the Engle-Granger test for co-integration the residuals of the model are stationary I (0), which eliminates the possibility of spurious regression. Further we address the problem of autocorrelation through the transformation into the ADL model. 
Table 3

ADL Model I

\begin{tabular}{|l|c|c|c|c|}
\hline \multicolumn{5}{|c|}{ Dependent variable: EXCZE } \\
\hline Variable & Coefficient & Std. Error & t-Statistic & Prob. \\
\hline C & -25.00962 & 7.868903 & -3.178285 & 0.0027 \\
\hline EXCZE(-1) & 0.590894 & 0.123966 & 4.766568 & 0.0000 \\
\hline GDPGER & 0.128466 & 0.013149 & 9.769827 & 0.0000 \\
\hline GDPGER(-1) & -0.071694 & 0.020764 & -3.452742 & 0.0012 \\
\hline R-squared & & & Durbin-Watson stat & 1.885498 \\
\hline F-statistic & & Prob (F-statistic) & 0.000000 \\
\hline Diagnostics tests & & Statistics & Prob. \\
\hline Breusch-Godfrey Serial Correlation LM Test: & 0.029765 & 0.9707 \\
\hline Jarque-Bera Test & & 18017.917 & 0.084343 & 0.6016 \\
\hline ARCH Test & & & & 0.7728 \\
\hline
\end{tabular}

Source: own calculations

Final ADL model (Table 3) can be written as follows

$$
\widehat{E X C Z E_{t}}=-25.00962+0.590894 E X C Z E_{t-1}+0.128466 G D P G E R_{t}-0.071694 G D P G E R_{t-1} \text {, }
$$

It follows that Czech exports depend both on its lagged value in time $t$ - 1 and on German GDP in time $t$ and $t-1$. Further we re-write the model in form of EC model:

$$
\triangle E \widehat{X C Z} E_{t}=-61.1324+0.1285 G D P G E R_{t}-0.4091\left(E X C Z E_{t-1}-0.1388 G D P G E R_{t-1}\right) .
$$

From the EC model we see how fast the system tends to long-term equilibrium in case of the deviation of the current state from its long-run relationship as measured by parameter $\gamma(0.4091)$ and the long-term relationship between the variables as measured by multiplier $\beta(0.1388)$. The long-term relationship is expressed by the term EC, which is given by the equation

$$
E C_{t}=E X C Z E_{t}-0.1388 G D P G E R_{t} .
$$

It is clear that Czech exports directly depend on German GDP. Diagnostic control of the model indicates unsystematic part of the model to be white noise process (Breusch, Godfrey, 1986, Jarque, Bera, 1980 and Darnell, 1994). 


\subsection{Dependence of Czech exports and German domestic absorption and exports}

\section{Figure 2}

Czech Exports (in billion EUR), German Absorption (in billion EUR) and German Exports (in billion EUR) in the Period of $1 / 2000-11 / 2012$ (data has been normalized) ${ }^{2}$

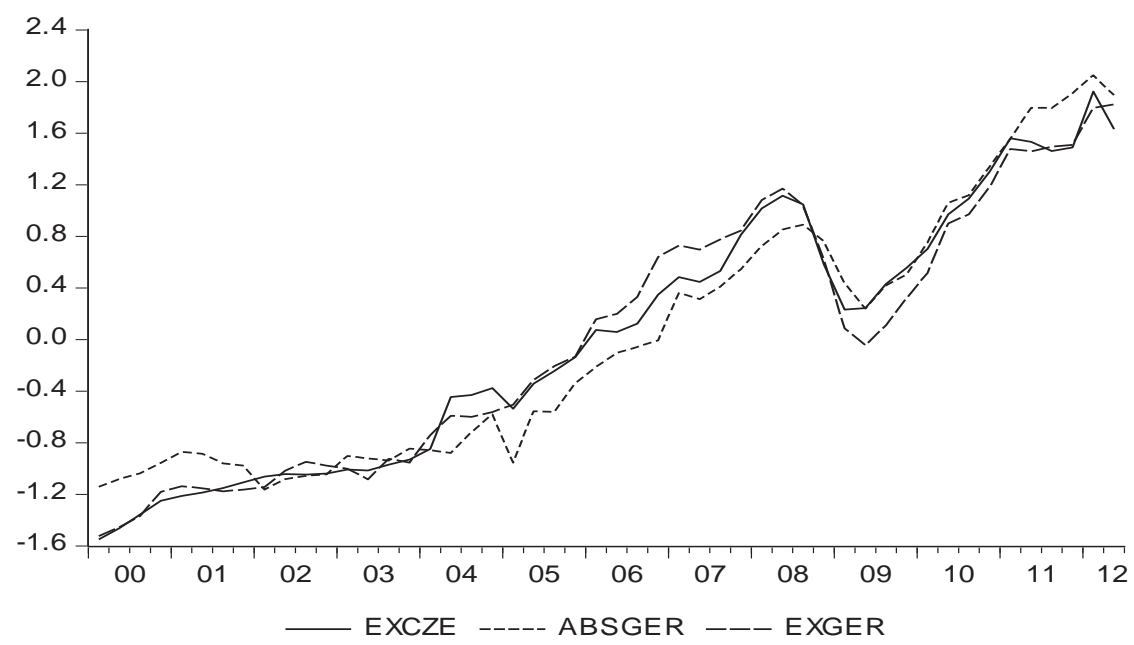

Source: data from Czech National Bank and German Statistical Office

Following the methodology from the previous subchapter we find that all analysed time series are non-stationary of the order 1, i. e. I (1). Furthermore, we employ the EngleGranger test for co-integration in order to avoid the spurious regression. The residuals of the model are stationary of the order one $\mathrm{I}(0)$. At the same time, we find a significant residual autocorrelation.

\section{Table 4}

Engle-Granger Test for Co-integration

\begin{tabular}{|l|c|c|c|c|}
\hline \multicolumn{5}{|c|}{ Null hypothesis: Series are not cointegrated } \\
\hline Dependent & tau-statistic & Prob. & z-statistic & Prob. \\
\hline EXCZE & -7.322317 & 0.0018 & -47.62151 & 0.0015 \\
\hline ABSGER & -6.252149 & 0.0196 & -38.84900 & 0.0187 \\
\hline EXGER & -5.601240 & 0.0468 & -34.38235 & 0.0273 \\
\hline
\end{tabular}

Source: own calculations

Time series are co-integrated. The conclusive ADL model can be found in Table 5 .

2 Where appropriate, we have normalized the data to have mean 0 and variance 1. 
Table 5

ADL Model II

\begin{tabular}{|l|c|c|c|c|}
\hline \multicolumn{5}{|c|}{ Dependent variable: EXCZE } \\
\hline Variable & Coefficient & Std. Error & t-Statistic & Prob. \\
\hline C & -12.01821 & 4.758468 & -2.525647 & 0.0152 \\
\hline EXCZE(-1) & 0.630292 & 0.117395 & 5.369006 & 0.0000 \\
\hline ABSGER & 0.021745 & 0.010244 & 2.122685 & 0.0394 \\
\hline EXGER & 0.093739 & 0.010115 & 9.267423 & 0.0000 \\
\hline EXGER(-1) & -0.064892 & 0.014635 & -4.434047 & 0.0001 \\
\hline R-squared & 0.992462 & Durbin-Watson stat & 1.81126 \\
\hline F-statistic & 1448.197 & Prob(F-statistic) & 0.00000 \\
\hline Diagnostics tests & & Statistics & Prob. \\
\hline Breusch-Godfrey Serial Correlation LM Test: & 0.142996 & 0.8672 \\
\hline \multicolumn{7}{|c|}{ Jarque-Bera Test } & 7.274891 & 0.0263 \\
\hline ARCH Test & & 1.634971 & 0.2074 \\
\hline
\end{tabular}

Source: own calculations

From the Table 5 we can derive following equation

$$
\widehat{E X C Z E_{t}}=-12.01821+0.6303 \text { EXCZE }_{t-1}+0.0217 A B S G E R_{t}+0.0937 \text { EXGER }_{t}-0.0649 \text { EXGER }_{t-1} .
$$

The Czech exports depend on its lagged value in time $t-1$, on German domestic absorption in time $t$ and on German exports in time $t$ and $t-1$. Furthermore, we re-write the model in form of EC model:

$$
\begin{aligned}
\triangle E X C Z E_{t} & =-32.5073+0.02174 A B S G E R_{t}+0.0937394 E X G E R_{t}- \\
& -0.3697\left(E X C Z E_{t-1}-0.0588 A B S G E R_{t-1}-0.2535 E X G E R_{t-1}\right) .
\end{aligned}
$$

From the EC model we see how fast the system tends to long-term equilibrium in the case of the deviation of the current state from its long-term relationship as measured by parameter $\gamma(0.3697)$ and the long-term relationship between the variables as measured by both multipliers $\beta$ ( 0.0588 and 0.2535$)$. The long-term relationship is expressed by the term $\mathrm{EC}$, which is given by the equation:

$$
E C_{t}=E X C Z E_{t}-0.0588 A B S G E R_{t}-0.2535 E^{2 X G E R_{t}} .
$$

It is clear that Czech exports directly depend proportionally on German domestic absorption and on German exports. Diagnostic control of the model indicates that unsystematic part of the model is white noise process (Breusch, Godfrey, 1986, Jarque, Bera, 1980, Darnell, 1994). 


\subsection{Dependence of Czech exports and German private consumption, German gross domestic investments and German government expenditures}

\section{Figure 3}

Czech Exports (in billion EUR), German Private Consumption (in billion EUR), German Gross Domestic Investments (in billion EUR) and German Government Expenditures (in billion EUR) in the Period of I/2000-II/2012 (data has been normalized)

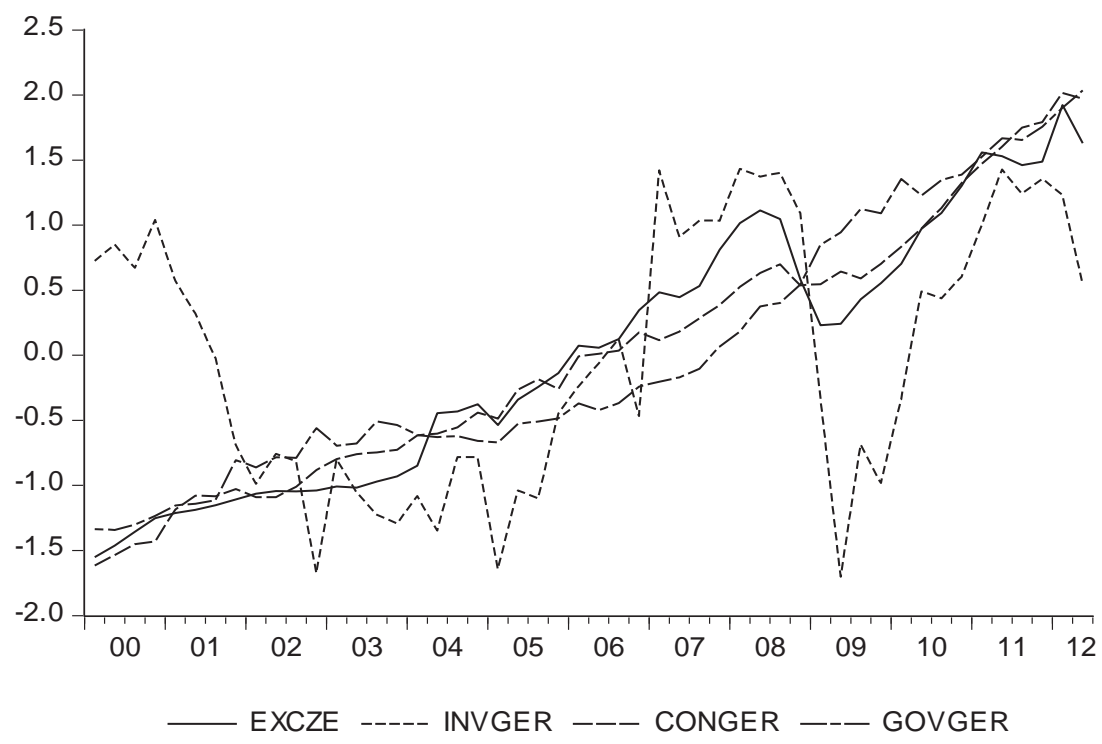

Source: data from Czech National Bank and German Statistical Office

All analysed time-series are non-stationary of the order 1, i.e. I (1) as it can be seen from the Table 1. The Engle-Granger test for co-integration (see Table 6) has, however, excluded the German government expenditures from the analysis. For all other time series co-integration relationship has been proven. 
Table 6

Engle-Granger Test for Co-integration

\begin{tabular}{|l|c|c|c|c|}
\hline \multicolumn{5}{|c|}{ Null hypothesis: Series are not cointegrated } \\
\hline Dependent & tau-statistic & Prob. & z-statistic & Prob. \\
\hline EXCZE & -5.280358 & 0.0082 & -31.53577 & 0.0064 \\
\hline INVGER & -5.173247 & 0.0104 & -31.07318 & 0.0075 \\
\hline CONGER & -4.721031 & 0.0276 & -26.84319 & 0.0292 \\
\hline GOVGER & -2.574431 & 0.6530 & -9.546541 & 0.7677 \\
\hline
\end{tabular}

Source: own calculations

The final ADL model can be derived from the Table 7 and expressed in the equation below.

Table 7

ADL Model III

\begin{tabular}{|l|c|c|c|c|}
\hline \multicolumn{5}{|c|}{ Dependent variable: EXCZE } \\
\hline Variable & Coefficient & Std. Error & t-Statistic & Prob. \\
\hline EXCZE(-1) & 0.961340 & 0.022269 & 43.16927 & 0.0000 \\
\hline INVGER & 0.070218 & 0.021448 & 3.273890 & 0.0021 \\
\hline INVGER(-1) & -0.086873 & 0.020884 & -4.159716 & 0.0001 \\
\hline CONGER & 0.284615 & 0.056411 & 5.045429 & 0.0000 \\
\hline CONGER(-1) & -0.277296 & 0.056369 & -4.919288 & 0.0000 \\
\hline R-squared & 0.986382 & Durbin-Watson stat & 1.929764 \\
\hline Diagnostics tests & & Statistics & Prob. \\
\hline Breusch-Godfrey Serial Correlation LM Test: & 1.088143 & 0.3461 \\
\hline Jarque-Bera Test & & 10.22039 & 0.0060 \\
\hline ARCH Test & & 0.034958 & 0.8525 \\
\hline
\end{tabular}

Source: own calculations

$$
\begin{aligned}
& \widehat{E X C Z E_{t}}=0.9613 E X C Z E_{t-1}+0.0702 I N V G E R_{t}-0.0869 I N V G E R_{t-1}+ \\
& +0.2846 C O N G E R_{t}-0.2773 \text { CONGER } R_{t-1} .
\end{aligned}
$$

The Czech exports depend on its lagged value in time $t$ - 1, on German gross domestic investments in time $t$ and $t-1$, and on German private consumption in time $t$ and $t-1$. Furthermore, we re-write the model in the form of the EC model: 


$$
\begin{aligned}
& \widehat{E X C Z E_{t}}=0.0702 \triangle I N V G E R_{t}+0.2846 \triangle C O N G E R_{t}- \\
& \text { - 0.0387(EXCZE } \left.E_{t-1}-0.4308 I N V G E R_{t-1}-0.1893 C O N G E R_{t-1}\right) \text {. }
\end{aligned}
$$

From the EC model we see how fast the system tends to long-term equilibrium in the case of the deviation of the current state from its long-term relationship as measured by parameter $\gamma(0.0387)$ and the long-term relationship between the variables as measured by both multipliers $\beta$ ( 0.4308 and 0.1893$)$. The long-term relationship is expressed by the term $\mathrm{EC}$, which is given by the equation

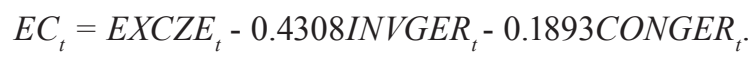

The Czech exports directly and proportionally depend on German gross domestic investments and on German private consumption. Diagnostic control of the model indicates that unsystematic part of the model is a white noise process (Breusch, Godfrey, 1986, Jarque, Bera, 1980 and Darnell, 1994).

\section{Analysis of Commodity Structure - Development and Trends}

When analysing foreign trade, one should always take commodity structure into account because it reveals the qualitative features of trade, and provides a deeper insight into the patterns of trade. The quality of trade can be considered to be of at least the same importance as the volume (quantity) of trade itself.

The commodity structure of both country's exports and imports is being influenced by variety of factors. Starting with Smith (Smith, 2001) and Ricardo (Ricardo, 1817) who explained the patterns of trade using differences in unit labour requirements and the Heckscher-Ohlin (Vanek-Samuelson-Rybczinski) model (Ohlin, 1967, Vanek, 1968, Stolper, Samuleson, 1941, Rybczinski, 1955) based on factor proportions we can arrive at the modern trade theories represented typically by Krugman (1979), Deardorff (1982), Romalis (2004) and others. Although focused on economies of scale, imperfect competition, intra-industry trade and other aspects, modern trade economists are actually still searching for the validity of Heckscher-Ohlin.

In this section we focused on the comparison of the commodity structure of exports to Germany in 2000 and 2011, as well as the determination of the key features and trends. Data from the Czech Statistical Office have been used.

\subsection{Commodity structure of Czech exports to Germany in $\mathbf{2 0 0 0}$}

The commodity structure of Czech exports to Germany, based on the SITC Classification, shows the great importance of groups 6 (Manufactured goods classified chiefly by material), 7 (Machinery and transport equipment) and 8 (Miscellaneous manufactured articles); see Figure 4. The share of these three groups of total exports to Germany was about 87 per cent in 2000. Moreover, the share of group 7 of total exports to Germany was 47 per cent. Other groups' share (13 per cent) seems to be irrelevant in that year. Czech exports to Germany in 2000 can be considered as highly concentrated within these three groups as classified by the SITC. However, this is a typical feature of Czech exports in general. 


\section{Figure 4}

\section{Commodity Structure of the Czech Republic's Exports to Germany in 2000}

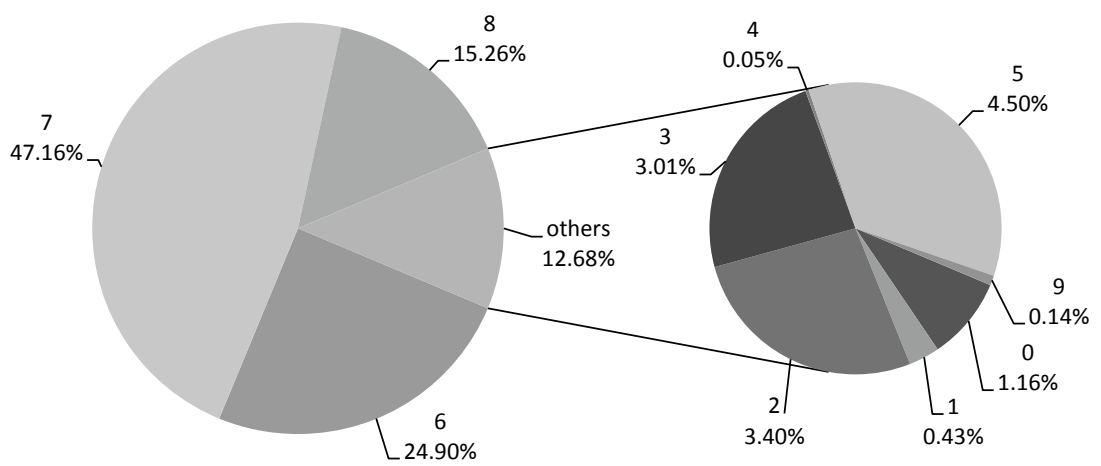

0 Food and live animals

1 Beverages and tobacco

2 Crude materials, inedible, except fuels

3 Mineral fuels, lubricants and related materials

4 Animal and vegetable oils, fats and waxes

Source: Czech Statistical Office
5 Chemicals and related products, n.e.s.

6 Manufactured goods classified chiefly by material

7 Machinery and transport equipment

8 Miscellaneous manufactured articles

9 Commodities and transactions not classified elsewhere in the SITC

The importance of group 7 for Czech exports to Germany actually is so high that it deserves more analysis. Deeper insight says that two groups are much more important than the others. Group 77 (Electrical machinery, apparatus and appliances) with 31\% and group 78 (Road vehicles) with $30 \%$ share in group 7 exports to Germany together account for almost $29 \%$ of total Czech exports to Germany, see the Figure 5.

\section{Figure 5}

Commodity Structure of the Czech Republic Exports to Germany in 2000, Group 7 in Detail

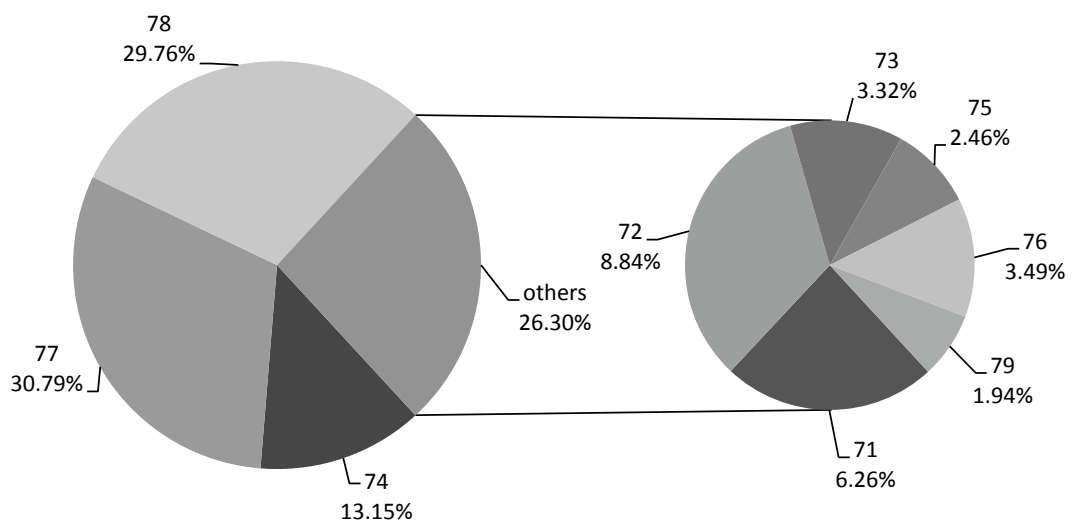

71 Power-generating machinery and equipment

72 Machinery specialized for particular industries

73 Metalworking machinery

74 General industrial machinery and equipment, n.e.s.

75 Office machines and automatic data-processing machines
76 Telecommunications and sound-recording

77 Electrical machinery, apparatus and appliances, n.e.s.

78 Road vehicles

79 Other transport equipment

Source: Czech Statistical Office 
This is not surprising because the Czech Republic's main specialization has long been the production of vehicles. Nevertheless, group 74 (General industrial machinery and equipment) shows an importance of $13 \%$.

We can attempt to analyse the above mentioned groups 77 and 78 in more detail. Using the 3-digit SITC Classification we would get following figures and results.

\section{Figure 6}

Commodity Structure of the Czech Republic Exports to Germany in 2000, Group 77 in Detail

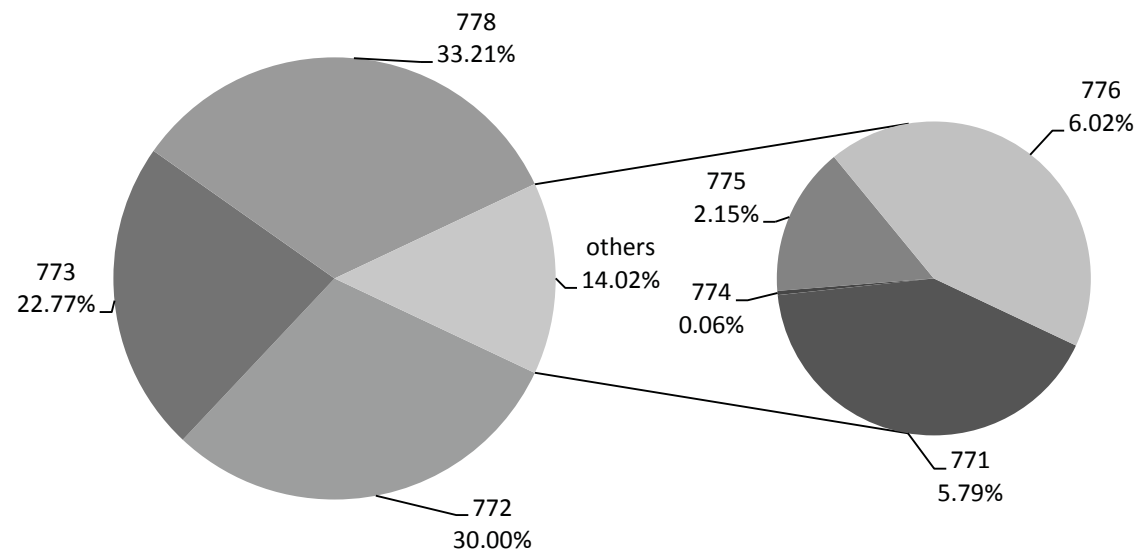

771 Electric power machinery and parts thereof

772 Electrical apparatus for switching or protecting electrical circuits or for making connections to or in electrical circuits

773 Equipment for distributing electricity, n.e.s.

774 Electrodiagnostic apparatus for medical and surgical purposes

775 Household-type electrical and non-electrical equipment, n.e.s.

776 Thermionic, cold and photo cathode, diodes, transistors and similar semiconductor devices

777 Electrical machinery and apparatus, n.e.s.

Source: Czech Statistical Office

Starting with the group 77 we can see (Figure 6) that there are three subgroups (772 - Electrical apparatus for switching or protecting electrical circuits or for making connections to or in electrical circuits (30\%), 773 - Equipment for distributing electricity (23\%), and 778 - Electrical machinery and apparatus (33\%)), which are much more important than others. 


\section{Figure 7}

Commodity Structure of the Czech Republic's Exports to Germany in 2000, Group 78 in Detail

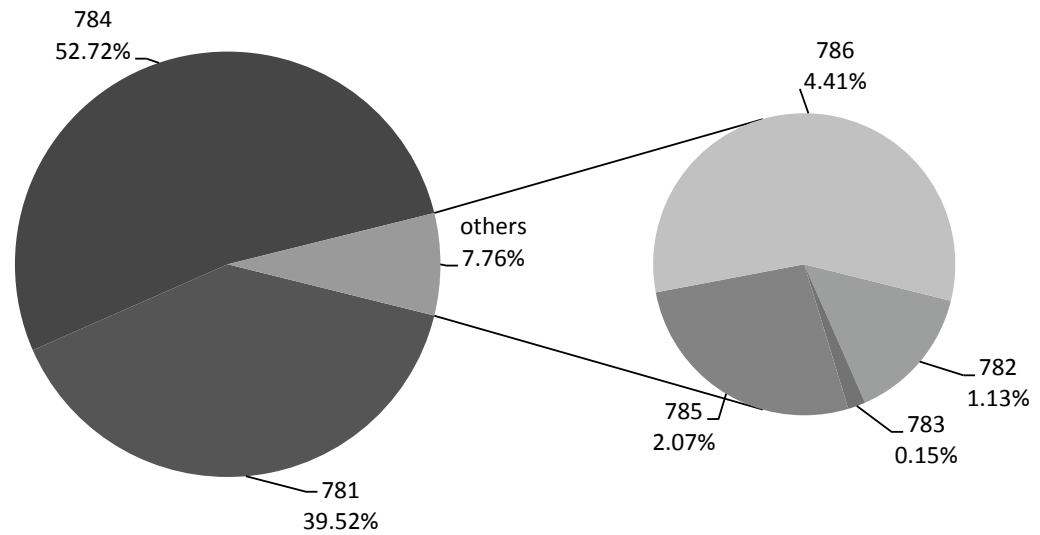

781 Motor cars and other motor vehicles for the transport of persons

782 Motor vehicles for the transp. of goods and specific purpose motor vehicles

783 Road motor vehicles, n.e.s.

784 Parts and accessories of the motor vehicles

785 Motor cycles (including mopeds) and cycles, invalid carriages

786 Trailers and semi-trailers; other vehicles, not mechanically propelled

Source: Czech Statistical Office

Continuing with group 78 (Figure 7) we can see that it actually consists of two relevant subgroups (781 - motor cars and other motor vehicles, principally designed for the transport of persons (other than motor vehicles designed for the transport of ten or more persons, including the driver), including station-wagons and racing cars (40\%), and 784 - spare parts and accessories for the motor vehicles of the groups 722, 781, 782 and $783(53 \%))$.

\subsection{Commodity structure of Czech exports to Germany in 2011}

The commodity structure of Czech exports to Germany changed significantly during the period 2000-2011. The relevance of the most important group 7 increased further from $47 \%$ in 2000 , to $59 \%$ in 2011 at the expense of almost all the other groups, especially the above mentioned groups 6 (decline from 25\% in 2000 to $17 \%$ in 2011) and 8 (from $15 \%$ in 2000 to $12 \%$ in 2011) (Figure 8). The trend during that period was a significant increase in concentration instead of the recommended diversification which would diminish the dependency of Czech exports to Germany (and the Czech economy as a whole) on group 7. 


\section{Figure 8}

\section{Commodity Structure of the Czech Republic's Exports to Germany in 2011}

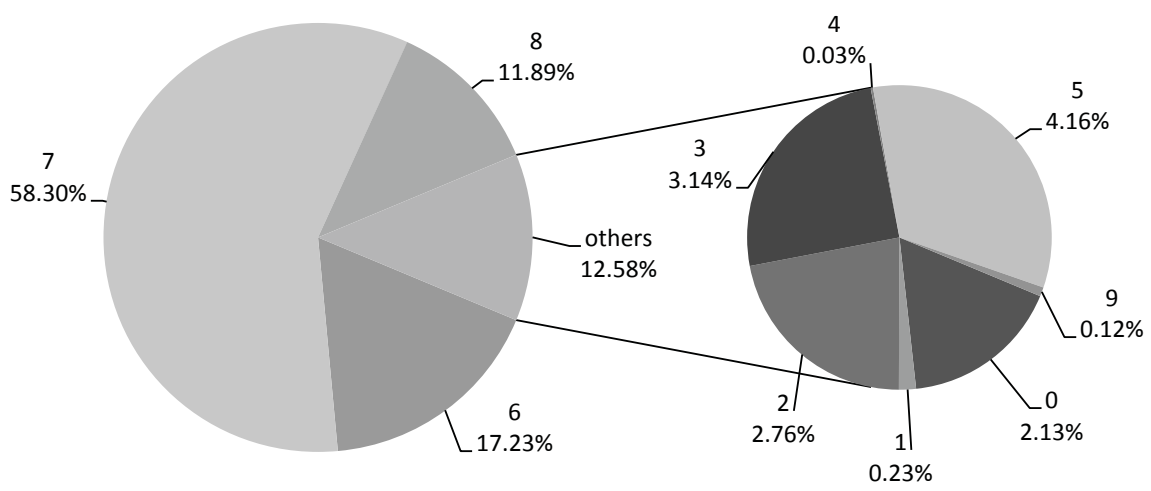

0 Food and live animals

1 Beverages and tobacco

2 Crude materials, inedible, except fuels

3 Mineral fuels, lubricants and related materials

4 Animal and vegetable oils, fats and waxes

Source: Czech Statistical Office
5 Chemicals and related products, n.e.s.

6 Manufactured goods classified chiefly by material

7 Machinery and transport equipment

8 Miscellaneous manufactured articles

9 Commodities and transactions not classified elsewhere in the SITC

\section{Figure 9}

Commodity Structure of the Czech Republic's Exports to Germany in 2011, Group 7 in Detail

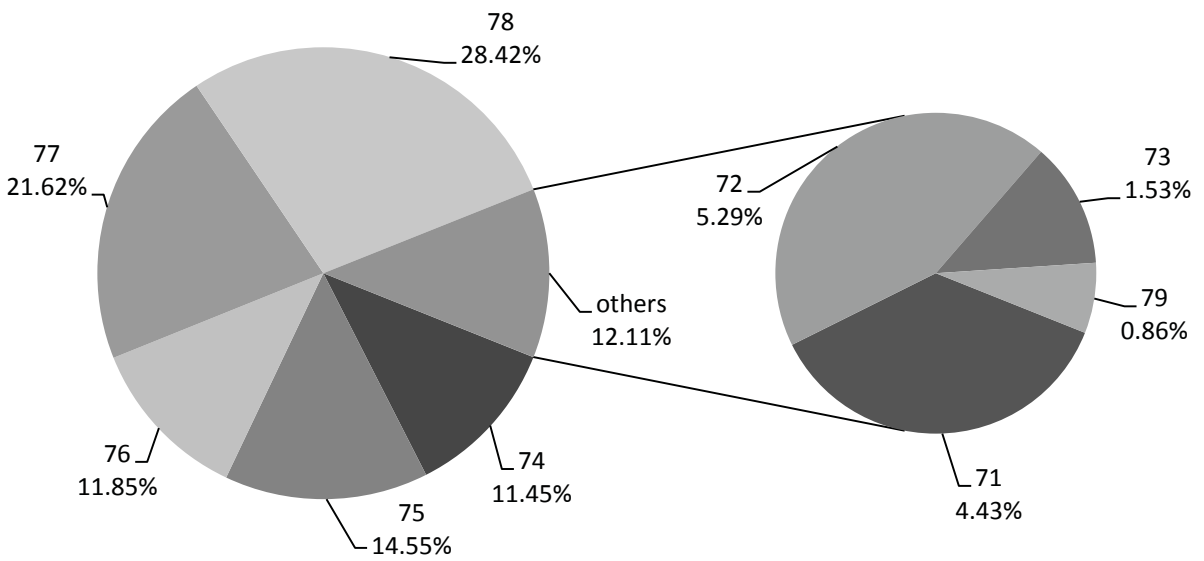

71 Power-generating machinery and equipment

72 Machinery specialized for particular industries

73 Metalworking machinery

74 General industrial machinery and equipment, n.e.s. 79 Other transport equipment

75 Office machines and automatic data-processing machines

Source: Czech Statistical Office
76 Telecommunications and sound-recording

77 Electrical machinery, apparatus and appliances, n.e.s.

78 Road vehicles 
Analysing the change in the structure of group 7 by comparing Figure 9 and Figure 5, we can conclude that diversification took place within this group. The share of the most relevant group 78 , declined from $31 \%$ to $22 \%$, the share of the second most important group 77 , decreased from $30 \%$ to $28 \%$, and this group became the most important item within group 7. On the other hand, two groups have shown significant positive changes in their shares (75 - Office machines and automatic data-processing machines, from $2 \%$ to $15 \%$; and 76 - Telecommunications and sound-recording and reproducing apparatus and equipment, from $4 \%$ to $12 \%$ ).

This means that Czech exports to Germany are getting more and more concentrated in group 7. Nevertheless, within this group we can see the opposite taking place: diversification.

\section{Figure 10}

\section{Commodity Structure of the Czech Republic's Exports to Germany in 2011, Group 77 in Detail}

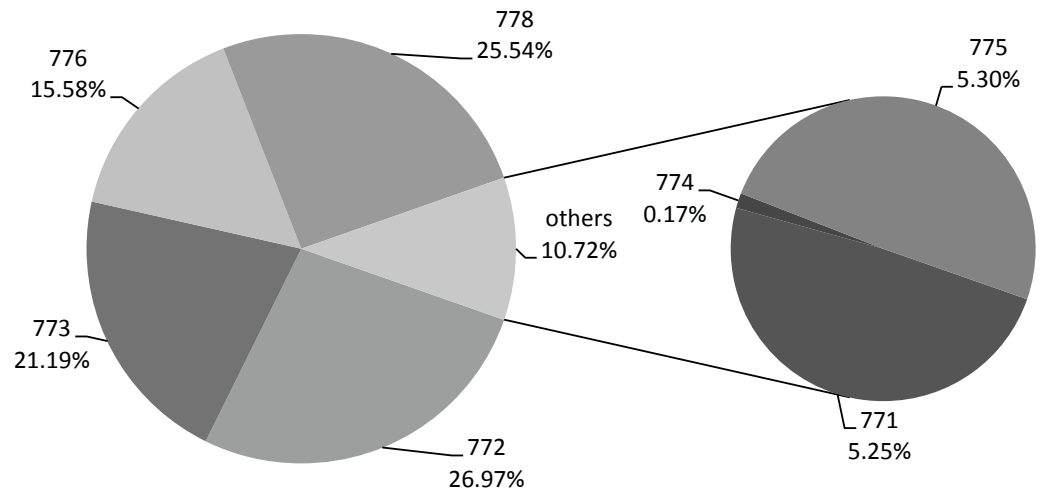

771 Electric power machinery and parts thereof

772 Electrical apparatus for switching or protecting electrical circuits or for making connections to or in electrical circuits 773 Equipment for distributing electricity, n.e.s.

774 Electrodiagnostic apparatus for medical and surgical purposes

775 Household-type electrical and non-electrical equipment, n.e.s.

776 Thermionic, cold and photo cathode, diodes, transistors and similar semiconductor devices

777 Electrical machinery and apparatus, n.e.s.

Source: Czech Statistical Office

As mentioned above, at the beginning of the period which was analysed in 2000 , the structure of group 77 (the most important subgroup within the group 7) was concentrated in three subgroups $(772,773$ and 778$)$. At the end of this period, the structure of group 77 was more diversified (Figure 10) because the relevance of the group 776 (Thermionic, cold cathode or photo-cathode valves and tubes; diodes, transistors and similar semiconductor devices; photosensitive semiconductor devices; light-emitting diodes; mounted piezoelectric crystals; electronic integrated circuits and micro-assemblies; as well was parts thereof) soared from $6 \%$ in 2000 to $16 \%$ in 2011). Moreover, the share of the subgroup 775 increased from 2\% in 2000 to 5\% in 2011, which means that in 2011 exports within group 77 were diversified almost perfectly. 


\section{Figure 11}

\section{Commodity Structure of the Czech Republic's Exports to Germany in 2011, Group 78 in Detail}

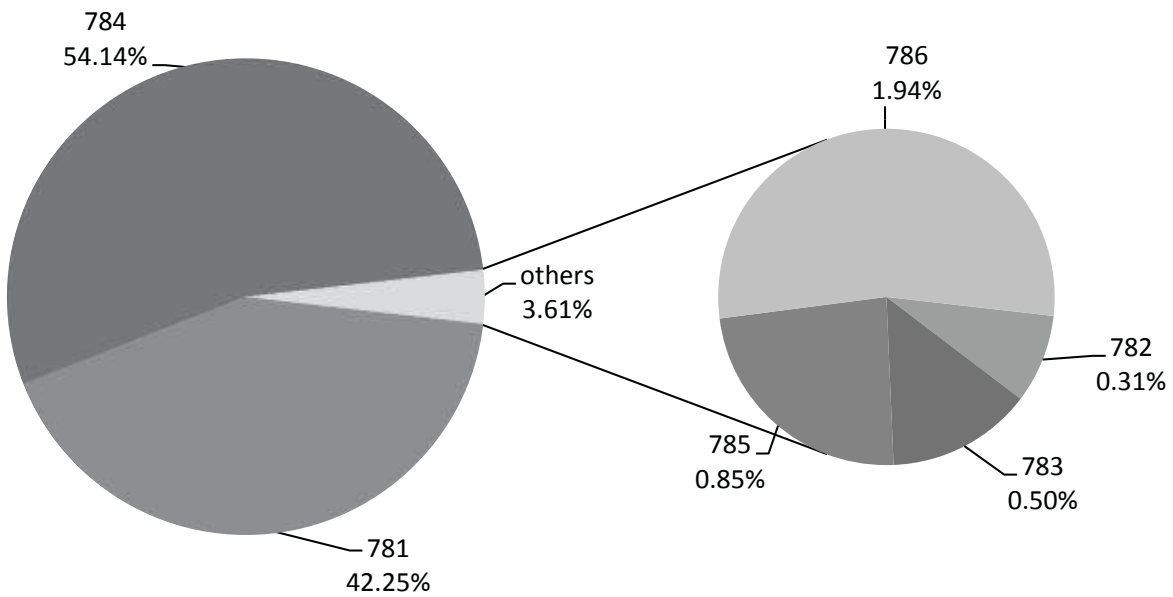

781 Motor cars and other motor vehicles for the transport of persons

782 Motor vehicles for the transp. of goods and spec.-purpose motor vehicles

783 Road motor vehicles, n.e.s.

784 Parts and accessories of the motor vehicles

785 Motor cycles (including mopeds) and cycles, invalid carriages

786 Trailers and semi-trailers; other vehicles, not mech.-propelled

Source: Czech Statistical Office

Conversely, the diversification of Czech exports to Germany which was included in the second most important subgroup within group 7; i.e., group 78, was very low in 2000. It was concentrated in just two subgroups 781 and 784. Furthermore, instead of diversification, this concentration was actually increased during the period under analysis. The share of these two groups, combined, increased from 93\% in 2000 to $96 \%$ in 2011 . $^{3}$

Nevertheless, the main purpose of the commodity structure analysis has been to support the findings of the co-integration analysis which proved that Czech exports depend on both German absorption and German exports.

Figure 8 shows that using SITC Classification there are actually just three groups $(6,7,8)$ playing an important role in Czech exports to Germany, with a total share of $88 \%$ in 2011. Thus, the share of the rest may be ignored.

We assume that all the goods included in the three relevant groups can be divided into two basic groups - final goods and semi-finished goods or parts. It is obvious that final goods are usually absorbed by private consumption, private investments or government expenditures (absorption), and semi-finished goods or parts are usually exported as parts of final products manufactured in Germany, to other countries or are used to produce consumer goods sold directly in Germany.

3 The concentration gets even more visible, if we use NACE classification, because these two subgroups are products of just one two-digital NACE industry. 
In-depth analysis of these three groups shows that groups 6 and 8 (with a total share of Czech exports, to Germany in 2011, of 29\%) include final products. It means that most of these are absorbed by the German economy. However, the same cannot be said about group 7 (with a share of 59\% in 2011). Figure 9 demonstrates that within this group there were five subgroups with a share higher than $10 \%(74,75,76,77$, and 78$)$ in that year. Four of these groups $(74,75,76$, and 77 ) include final products (with a negligible share of spare parts) and are absorbed as well. Group 78 (Road vehicles) actually consists of just two relevant subgroups (781, and 784) with a total share of 96\% in 2011 (see Figure 11). Group 781 (motor cars and other motor vehicles principally designed for the transport of persons) with a share of $42 \%$, includes final products and it may be assumed that it is absorbed by the German economy as well. However, the second, even more relevant, group 784 (spare parts and accessories for motor vehicles) with its share of 54\% represents semi-finished products or parts, and is assumed to be mostly exported to third countries in final products by German companies. The share of this subgroup 784 of total Czech exports to Germany is almost $9 \%$ which should definitely be taken into account.

\section{Conclusions}

The main goal of our paper was to provide an in-depth analysis of the relationship between Czech exports and German GDP. For this purpose we have run 3 rounds of co-integration analysis, as well as constructing 3 ADL and 3 EC models to investigate short- and longterm relations between: 1) Czech exports and German GDP: 2) Czech exports and German domestic absorption and German exports, and finally: 3) Czech exports and German private consumption, German investments and German government expenditures. We have found statistically significant long-term relations between: 1) Czech exports and German GDP; 2) between Czech exports and German domestic absorption and German exports; and 3) between Czech exports and German private consumption and German investments. We have not found any long-term relationship between Czech exports and German government expenditures.

Since we have proven the respective time series to be co-integrated, we may conclude that Czech exports strongly, and on long-term basis, depend on German GDP. However, it does not depend only on German consumption as is usually assumed by the theory. It significantly depends also on German exports to third countries, as well as on German investments which are further used to produce goods for both domestic consumption and exports abroad.

The findings of the co-integration analysis have been further supported by the analysis of commodity structure of Czech exports to Germany. The exports are very concentrated, whereas the concentration has significantly increased during the period under analysis. Apart from final goods, there is also a significant amount of spare parts and semi-finished products among the Czech exports to Germany, which can be used to produce consumer goods sold both in Germany and abroad.

This highly concentrated specific export structure, and statistically significant longterm dependence of Czech exports on German private consumption; investments and exports show that the relationship between Czech exports and German GDP is a very complex one. We therefore consider the Czech economy to be strongly integrated into German distribution channels. From this perspective, the Czech economy serves as a specialized outsourced production capacity for the Germany economy. 


\section{References}

Agosin, M. R., Alvarez, R., Bravo-Ortega, C. (2012), "Determinants of Export Diversification around the World: 1962-2000." World Economy, Vol. 35, No. 3, pp. 295-315.

Ali, B., Sami, M. (2011), "Determinants of Tunisia's Exports: A Gravity Model Framework." Empirical Economics Letters, Vol. 10, No. 4, pp. 347-58.

Arlt, J., Guba, M., Radkovský, Š., Sojka, M., Stiller, V. (2001), “Vliv vybraných faktorů na vývoj poptávky po penězích v letech 1994-2000." Politická ekonomie, Vol. 49, No. 5, pp. 635-657.

Arlt, J., Arltová, M. (2009), Ekonomické časové řady. Prague: Professional Publishing.

Balassa, B. (1964), "The Purchasing-Power Parity Doctrine: A Reappraisal." The Journal of Political Economy, Vol. 72, No. 6, pp. 584-596.

Blanchard, J. O., Fischer, S. (2000), "Lectures on Macroeconomics." London: The MIT Press.

Breusch, T., Godfrey, L. G. (1986), "Data Transformation Tests.” Economic Journal, 96 (Souplement), pp. 47-58.

CZSO (2012), External Trade. Volume 2012, Ref. No. 1222/2012-44, Prague: Czech Statistical Office.

Čihák, M., Holub, T. (2000), "Cenová konvergence k Evropské unii - problém relativních cen." Politická ekonomie, Vol. 48, No. 5, pp. 660-670.

Darnell, A. C. (1994), A Dictionary of Econometrics. Edward Elgar.

Deardorff, A. V. (1982), "The General Validity of Heckscher-Ohlin Theorem." American Economic Review, Vol. 72, No. 4, pp. 683-694.

Dickey, D. A., Fuller, W. A. (1979), “Distribution of Estimators for Autoregressive Time Series with a Unit Root." Journal of American Statistical Association, Vol. 74, No. 366, pp. 427-431.

Dungey, M. (2004), "Identifying Terms of Trade Effects in Real Exchange Rate Movements: Evidence from Asia." Journal of Asian Economics, Vol. 15, No. 2, pp. 217-235.

Engle, R. F., Granger, C. W. J. (1987), “Cointegration and Error Correction Representation: Estimation and Testing." Econometrica, Vol. 55, No. 2, pp. 251-276.

Gandolfo, G. (1986), International Economics. Berlin: Springer.

Granger, C. W. J., Newbold, P. (1974), "Spurious Regressions in Econometrics." Journal of Econometrics, Vol. 2, No. 2, pp. 111-120.

Havrlant, D., Hušek, R. (2011), "Models of Factors Driving the Czech Export." Prague Economic Papers, Vol. 20, No. 3, pp. 195-215.

Hendry, D., Pagan, A., Sargan, J. (1984), "Dynamic Specifications." Chapter 18 in Handbook of Econometrics, Vol. II (ed., Z. Griliches and M. Intriligator), North Holland.

Jarque, C., Bera, A. (1980), "Efficient Tests for Normality, Heteroscedasticity, and Serial Independence of Regression Residuals." Economics Letters, Vol. 6, No. 3, pp. 255-259.

Kaus, R. S. (2008), "An Inquiry into the Determinants of the Exports of China and India." China and World Economy, Vol. 16, No. 5, pp. 1-15.

Krugman, P. R., Obstfeld, M. (2000), "International Economics: Theory and Policy", Reading: Addison-Wesley.

Krugman, P. R. (1979), "Increasing Returns, Monopolistic Competition, and International Trade." Journal of International Economics, Vol. 9, No. 4, pp. 469-479.

Majeed, M. T., Ahmad, E. (2006), "Determinants of Exports in Developing Countries." Pakistan Development Review, Vol. 45, No. 4, pp. 1265-75.

Mandel, M., Tomšík, V. (2008), “External Balance in a Transition Economy: The Role of Foreign Direct Investments." Eastern European Economics, Vol. 46, No. 4, pp. 5-26.

Nešvera, V. (2006), "Ceny v obchodě České republiky se zeměmi Evropské unie." Politická ekonomie, Vol. 54, No. 2, pp. 214-226. 
Obstfeld, M., Rogoff, K. (1996), Foundations of International Macroeconomics. Cambridge; London: MIT Press.

Ohlin, B. (1967), Interregional and International Trade. Cambridge: Harvard University Press.

Pilbeam K. (1992), International Finance. London: Macmillan Press LTD.

Podkaminer, L. (2010), "Real Convergence and Price Levels: Long-Term Tendencies versus Short-Term Performance in the Enlarged European Union." Metroeconomica, Vol. 61, No. 4, pp. 640-64.

Ricardo, D. (1817), On the Principles of Political Economy and Taxation. London: John Murray.

Rojíček, M., Koštáková, T., Sixta, J. (2010), "Zahraniční obchod v pojetí platební bilance a národních účtů. Metodické změny v roce 2011" (Foreign Trade in the Concept of the Balance of Payments and National Accounts. Methodological Changes in 2011). Presentation, Workshop at the Czech Statistical Office and the Czech National Bank, Prague, 18.10.2010.

Rojíček, M., Koštáková, T., Sixta, J. (2011), "Zahraniční obchod v národním pojetí. Metodické změny a údaje za roky 2009-2010" (Foreign Trade in the National Concept. Methodological Changes and Data for the Years 2009-2010). Presentation, Workshop at the Czech Statistical Office, Prague, 7.3.2011.

Rojíček, M., Koštáková, T., Sixta, J. (2012), “Ownership Principle in the Foreign Trade Statistics: Czech Approach." Statistika, Vol. 49, No. 1, pp. 5-22.

Romalis, J. (2004), "Factor Proportions and the Structure of Commodity Trade." American Economic Review, Vol. 94, No. 1, pp. 67-97.

Rose, A. K. (2004), "Do We Really Know that the WTO Increases Trade?" American Economic Review. Vol. 94, No. 1, pp. 98-114.

Rybczinski, T. M. (1955), "Factor Endowments and Relative Commodity Prices." Economica, Vol. 22, No. 88, pp. 336-341.

Samuelson, P. A. (1964), "Theoretical Notes on Trade Problems." The Review of Economics and Statistics, Vol. 46, No. 2., pp. 145-154.

Smith, A. (2001), Pojednání o podstatě a původu bohatství národů. Prague: Liberální institut.

Stolper, W. F., Samuelson, P. A. (1941), "Protection and Real Wages." Review of Economic Studies, Vol. 9, No. 1, pp 58-73.

Tomšík, V. (2000), "Analysis of Foreign Trade in the Czech Republic." Eastern European Economics, Vol. 38, No. 6, pp. 43-68.

Tomšík, V. (2001), "Regresní analýza funkcí zahraničního obchodu ČR v letech 1993-1998." Finance a úvěr, Vol. 51, No. 1, pp. 46-58.

Turner, G. (2011), "Financial Geography and Access as Determinants of Exports." Cambridge Journal of Regions, Economy and Society, Vol. 4, No. 2, pp. 269-86.

U.S. Census Bureau (2004), X-12-ARIMA. Washington, DC: U.S. Census Bureau, U.S. Department of Commerce.

Vanek, J. (1968), "The Factor Proportions Theory: the N-Factor Case." Kyklos, Vol. 21, No. 4, pp. 749-756.

Vintrová, R. (2007), "Reálná a nominální konvergence v zemích středoevropské pětky." Politická ekonomie, Vol. 55, No. 2, pp. 206-25.

Vural, I. Y., Zortuk, M. (2011), "Foreign Direct Investment as a Determining Factor in Turkey's Export Performance." Eurasian Journal of Business and Economics, Vol. 4, No. 7, pp. 13-23.

Wilson, S. J., Mann, C. L., Otsuki, T. (2005), "Assessing the Potential Benefit of Trade Facilitation: Global Perspective," In: Dee, P. S.: Quantitative Methods for Assessing the Effects of Non-Tariff Measures and Trade Facilitation. River Edge: World Scientific Publishing Company Incorporated. 